\title{
Official Reports
}

Amended Commission Proposal, COM (2006) 83 final = Commission of the European Communities - Amended Proposal for a for a Regulation of the European Parliament and the Council on the Law Applicable to Non-Contractual Obligations ("Rome II"), COM (2006) 83 final

Commission Communication concerning the Council's Common Position on the Amended

Proposal for a Regulation of the European Parliament and the Council on the Law Applicable to Non-Contractual Obligations (“Rome II”), COM (2006) 566 final

Commission Proposal COM (2003) 427 final = Commission of the European Communities - Proposal for a Regulation of the European Parliament and the Council on the Law Applicable to Non-Contractual Obligations ("Rome II"), COM (2003) 427 final

Council's Common Position, OJ 2006 C/289E/68 = Common Position adopted by the Council on 25 September 2006 with a view to the adoption of a Regulation of the European Parliament and of the Council on the law applicable to non-contractual obligations ("Rome II”), OJ EC 2005 C 157E/371

Draft Report Wallis = Draft Report on the proposal for a regulation of the European Parliament and of the Council on the law applicable to non-contractual obligations ("Rome II") (COM(2003)0427 - C50338/2003 - 2003/0168(COD)), Committee on Legal Affairs, Rapporteur: Diana Wallis, PR\510106EN.doc - PE.349.977v02-00

House of Lords' Select Committee, Final Report “The Rome II Regulation”, $8^{\text {th }}$ Report of Session 2003-2004 (HL Paper 66) http://www.publications.parliament.uk/pa/ld200304/ldse lect/ldeucom/66/6602.htm

Opinion of the European Economic and Social Committee on the Proposal for a Regulation of the European Parliament and the Council on the Law Applicable to Non-Contractual Obligations (“Rome II”), OJ EC 2004 C 241/1

Recommendation of the Committee on Legal Affairs, A6-0481/2006 final = Recommendation on the Council common position for adopting a regulation of the European Parliament and of the Council on the law applicable to non-contractual obligations ("Rome II") (9751/ 7/2006 - C6-0317/2006 - 2003/0168(COD)), Committee on Legal Affairs, Rapporteur: Diana Wallis RR|378852EN.doc - PE 378.852v02-00

Report Wallis = Draft Report on the proposal for a regulation of the European Parliament and of the Council on the law applicable to non-contractual obligations ("Rome II") (COM (2003)0427 - C5-0338/2003 - 2003/0168(COD)), Committee on Legal Affairs, Rapporteur: Diana Wallis, RR\349977EN.doc - PE.349.977v0\$-00. 
